\title{
Editorial
}

Journal of Innate

Immunity
J Innate Immun 2018;10:1-2

DOI: $10.1159 / 000490363$
Published online: May 31, 2018

\section{The Balancing Act of Inflammation}

Sepsis is a common cause of admission to intensive care units. The pathophysiological processes occurring during the course of this clinical syndrome have become more complex with the achievements of modern medicine. An increasing number of patients are subject to complex treatments affecting the immune system, for example after transplantation and during chemotherapy. This also affects the sepsis survivors that are more frequently discharged from hospital and often experience long-term outcomes such as late mortality, immune dysfunction, secondary infections, impaired quality of life, and unplanned readmissions [1]. The immune dysfunctions causing sepsis are complex, and it has been difficult to achieve improved outcomes despite several randomized controlled trials $[2,3]$. Recent studies provide compelling evidence that dysregulated anti-inflammatory responses contribute to sepsis mortality. Thus, it is important to continue exploring immunological approaches for sepsis therapy [4]. Genetic vulnerability also seems to play a role in sepsis. TNF- $\alpha$ and associated genes were early on recognized as key mediators in response to lipopolysaccharide (LPS) $[5,6]$. In this issue of the Journal of Innate Immunity, Nakada et al. [7] tested the hypothesis that single nucleotide polymorphisms (SNPs) in $I L-10$, $I L-19, I L-20$, and $I L-24$ of the $I L-10$ family gene cluster alter the clinical outcome of septic shock. An SNP genotype of $I L-20$ was associated with elevated IL-20 produc- tion and increased adverse outcomes with $27 \%$ in patients with septic shock.

Innate immune cell responses are of critical importance where granulocytes are recruited and activated during early phases of systemic inflammation and contribute to acute lung injury and reperfusion injuries $[8,9]$. Neutrophils exert several host defense functions, and formation of neutrophil extracellular traps has caught widespread attention in recent years. These were initially recognized as a beneficial part of the innate host response but were, with time, also assigned detrimental roles during prolonged inflammation and sepsis [10-12]. Upon the various forms of cell death that occurs during inflammation, including formation of neutrophil extracellular traps, histones are released to the extracellular environment. Extracellular histones are potent activators of various innate immune responses and are considered key players in sepsis [13]. As a consequence, studies of histones in an extracellular context are important, in addition to their long-recognized roles in regulating transcriptional activities $[14,15]$.

One study in this issue shows that $\beta$-glucan and LPS synergistically worsen sepsis in a lupus model using FcGRIIb-/- mice [16]. The data suggest that therapeutic strategies addressing gut leakage may be of interest in sepsis conditions occurring in patients suffering from lupus. Finally, novel therapeutic targets are an urgent and large- 
ly unmet need in sepsis. The observation that PCSK9 reduces the clearance of endotoxin and therefore is a critical regulator of the innate immune response during infection is intriguing. During sepsis, PCSK9 levels are highly correlated with the development of subsequent multiple organ failure. As a consequence, inhibition of PCSK9 activity is an attractive target for treating the spectrum of sepsis and septic shock [17]. An interesting approach, using epinephrine to stimulate $\beta$-adrenergic receptors in sepsis, is presented by Shubin et al. [18] in this issue of the Journal of Innate Immunity. This suppressed the innate in- flammatory response to LPS in monocytic cells, adding to the known effects on the cardiovascular system.

Taken together, sepsis continues to be a challenge both for researchers and clinicians, and innate immune mechanisms attract increasing attention as promising targets in this complex syndrome. We hope that the readership of the Journal of Innate Immunity will find this issue interesting and hope for continued submissions advancing this and other fields in the dynamic area of innate immunity. Heiko Herwald, Lund Arne Egesten, Lund

\section{References}

$\checkmark 1$ Linder A, Guh D, Boyd JH, Walley KR, Anis AH, Russell JA: Long-term (10-year) mortality of younger previously healthy patients with severe sepsis/septic shock is worse than that of patients with nonseptic critical illness and of the general population. Crit Care Med 2014;42:2211-2218.

-2 van der Poll T, van de Veerdonk FL, Scicluna BP, Netea MG: The immunopathology of sepsis and potential therapeutic targets. Nat Rev Immunol 2017;17:407-420.

-3 Genga KR, Russell JA: Update of sepsis in the intensive care unit. J Innate Immun 2017;9: 441-455.

4 Okeke EB, Uzonna JE: In search of a cure for sepsis: taming the monster in critical care medicine. J Innate Immun 2016;8:156-170.

$\checkmark 5$ Beutler B, Milsark IW, Cerami AC: Passive immunization against cachectin/tumor necrosis factor protects mice from lethal effect of endotoxin. Science 1985;229:869-871.

-6 Thair SA, Topchiy E, Boyd JH, Cirstea M, Wang C, Nakada TA, Fjell CD, Wurfel M, Russell JA, Walley KR: TNFAIP2 inhibits early $\mathrm{TNF} \alpha$-induced NF-x03BA;B signaling and decreases survival in septic shock patients. J Innate Immun 2016;8:57-66.

7 Nakada TA, Wacharasint P, Russell JA, Boyd JH, Nakada E, Thair SA, Shimada T, Walley KR: The IL20 genetic polymorphism is associated with altered clinical outcome in septic shock. J Innate Immun 2018;10:179-186.
-8 Tak T, van Groenendael R, Pickkers P, Koenderman L: Monocyte subsets are differentially lost from the circulation during acute inflammation induced by human experimental endotoxemia. J Innate Immun 2017;9:464-474.

-9 Leliefeld PH, Wessels CM, Leenen LP, Koenderman L, Pillay J: The role of neutrophils in immune dysfunction during severe inflammation. Crit Care 2016;20:73.

-10 Brinkmann V, Reichard U, Goosmann C, Fauler B, Uhlemann Y, Weiss DS, Weinrauch Y, Zychlinsky A: Neutrophil extracellular traps kill bacteria. Science 2004;303:15321535.

11 Sabbione F, Keitelman IA, Iula L, Ferrero M, Giordano MN, Baldi P, Rumbo M, Jancic C, Trevani AS: Neutrophil extracellular traps stimulate proinflammatory responses in human airway epithelial cells. J Innate Immun 2017;9:387-402.

12 Leffler J, Prohászka Z, Mikes B, Sinkovits G, Ciacma K, Farkas P, Réti M, Kelen K, Reusz GS, Szabó AJ, Martin M, Blom AM: Decreased neutrophil extracellular trap degradation in Shiga toxin-associated haemolytic uraemic syndrome. J Innate Immun 2017;9: $12-21$.

$13 \mathrm{Xu}$ J, Zhang X, Pelayo R, Monestier M, Ammollo CT, Semeraro F, Taylor FB, Esmon NL, Lupu F, Esmon CT: Extracellular histones are major mediators of death in sepsis. Nat Med 2009;15:1318-1321.
4 Biron BM, Chung CS, O'Brien XM, Chen Y, Reichner JS, Ayala A: Cl-amidine prevents histone 3 citrullination and neutrophil extracellular trap formation, and improves survival in a murine sepsis model. J Innate Immun 2017;9:22-32.

15 Fattahi F, Grailer JJ, Lu H, Dick RS, Parlett M, Zetoune FS, Nuñez G, Ward PA: Selective biological responses of phagocytes and lungs to purified histones. J Innate Immun 2017;9: 300-317.

16 Issara-Amphorn J, Surawut S, Worasilchai N, Thim-Uam A, Finkelman M, Chindamporn A, Palaga T, Hirankarn N, Pisitkun P, Leelahavanichkul A: The synergy of endotoxin and $(1 \rightarrow 3)-\beta-D$-glucan, from gut translocation, worsens sepsis severity in a lupus model of $\mathrm{FC}$ gamma receptor IIb-deficient mice. J Innate Immun 2018;10:187-199.

-17 Boyd JH, Fjell CD, Russell JA, Sirounis D, Cirstea MS, Walley KR: Increased plasma PCSK9 levels are associated with reduced endotoxin clearance and the development of acute organ failures during sepsis. J Innate Immun 2016;8:211-220.

$\rightarrow 18$ Shubin NJ, Pham TN, Staudenmayer KL, Parent BA, Qiu Q, O'Keefe GE: A potential mechanism for immune suppression by betaadrenergic receptor stimulation following traumatic injury. J Innate Immun 2018;10: 200-212. 